BMJ Open

Ophthalmology

\title{
Reduced foveal cone density in early idiopathic macular telangiectasia
}

\author{
Hongxin Song (D) , ${ }^{1}$ Ethan A Rossi, ${ }^{2}$ David R Williams ${ }^{3,4}$
}

To cite: Song H, Rossi EA, Williams DR. Reduced foveal cone density in early idiopathic macular telangiectasia. BMJ Open Ophthalmology 2021;6:e000603. doi:10.1136/ bmjophth-2020-000603

Received 22 August 2020 Revised 30 November 2020 Accepted 20 December 2020
Check for updates

(C) Author(s) (or their employer(s)) 2021. Re-use permitted under CC BY-NC. No commercial re-use. See rights and permissions. Published by BMJ.

${ }^{1}$ Beijing Tongren Eye Center, Beijing Institute of Ophthalmology, Beijing Tongren Hospital, Capital Medical University, Beijing, China ${ }^{2}$ Department of Ophthalmology, University of Pittsburgh, Pittsburgh, Pennsylvania, USA ${ }^{3}$ Center for Visual Science, University of Rochester, Rochester, New York, USA ${ }^{4}$ Institute of Optics, University of Rochester, Rochester, New York, USA

Correspondence to Professor Hongxin Song; songhongxin2012@ccmu. edu.cn

\section{ABSTRACT}

Objective Idiopathic macular telangiectasia (MacTel) is considered primarily a vascular disease affecting juxtafoveal retinal capillaries. However, recent evidence suggests that neuronal changes may occur early in disease development. We used high-resolution adaptive optics retinal imaging to elucidate the foveal cone photoreceptor changes at a cellular level in patients with MacTel.

Methods and analysis We used adaptive optics scanning light ophthalmoscopy (AOSLO) to evaluate the foveal cone photoreceptors in the less-affected eye of patients with asymmetric MacTel. AOSLO images of cone photoreceptors were obtained in a $4^{\circ} \times 4^{\circ}$ area centred on the foveola. Individual cone positions were identified within a $2^{\circ} \times 2^{\circ}$ area centred on the fovea, using semiautomatic cone marking software with manual correction, permitting calculation of a map of cone density.

Results In all participants, one eye was affected with MacTel, the fellow eye was clinically normal or near normal, with visual acuity of 20/25 or better and subtle angiographic leakage. The foveal cone mosaics were continuous with tight packing and cones exhibited normal reflectivity. However, cone density was significantly lower for all participants (mean $=80733$ cones $/ \mathrm{mm}^{2}$ ) within $0.5^{\circ}$ than the cone density previously reported for normal eyes. Conclusions Foveal cone density is lower than normal in the clinically less-affected eyes of patients with asymmetric MacTel. This suggests that cone photoreceptor loss may precede classic obvious vascular changes in idiopathic MacTel.

\section{INTRODUCTION}

Idiopathic macular telangiectasia (MacTel) is considered a vascular anomaly affecting retinal capillaries in the juxtafoveal region of one or both eyes. It is characterised by slow but progressive loss of visual acuity, with morphological and functional changes being most pronounced on the temporal side of the foveola. ${ }^{1}$ Although it has been considered a vascular disease, recent high-resolution imaging evidence suggests that neuronal changes at the photoreceptor layer may occur early in disease development. ${ }^{23}$

Currently no data are available on cone photoreceptor density at the foveal centre in patients with MacTel, the most important area for spatial vision. In the present study, we used adaptive optics scanning light ophthalmoscopy (AOSLO) to image the cone

\section{Key messages}

What is already known about this subject? Idiopathic macular telangiectasia (MacTel) is considered primarily a vascular disease affecting juxtafoveal retinal capillaries.

\section{What are the new findings?}

- Using adaptive optics scanning light ophthalmoscopy (AOSLO) we found cone density was significantly lower in the clinically normal or near-normal eyes of the MacTel patients (mean $=80,733$ cones $/ \mathrm{mm} 2$ ) within 0.5 degrees than the cone density previously reported for normal eyes.

How might these results change the focus of research or clinical practice?

- Cone photoreceptor loss may precede classic obvious vascular changes in idiopathic MacTel.

photoreceptors in and around the foveal centre in three patients with asymmetric MacTel type 2.

\section{METHODS}

Study participants and clinical examinations

Three participants (men, 61-year-old twins and age 35) with a diagnosis of type $2 \mathrm{MacTel}$ (asymmetrical) were recruited for this study. The study protocol adhered to the tenets of the Declaration of Helsinki and was approved by the University of Rochester research subjects review board. Informed written consent was obtained after a full explanation of the procedures and consequences of this study both verbally and in writing. Patients or the public were not involved in the design, or conduct, or reporting or dissemination plans of our research. All subjects received a complete eye examination including fluorescein angiography. To accurately calculate the size of retinal features, axial length was measured with an IOL master (Carl Zeiss Meditec, Dublin, California, USA).

AOSLO imaging, cone density measurements and statistical analysis

Cone photoreceptor images were acquired using an AOSLO system and methods described in detail elsewhere. ${ }^{4}$ For all subjects 
Table 1 Clinical information of the three patients with MacTel

\begin{tabular}{|c|c|c|c|c|c|c|}
\hline Patient & Age & Gender & \multicolumn{2}{|l|}{ Family history } & MacTel eye & Less-affected eye \\
\hline 1 & 61 & Male & \multicolumn{2}{|c|}{ Twin brother (patient 2) affected } & OD & OS \\
\hline 2 & 61 & Male & \multicolumn{2}{|c|}{ Twin brother (patient 1) affected } & OD & os \\
\hline \multirow[t]{3}{*}{3} & 37 & Male & None & & OD & OS \\
\hline & \multicolumn{2}{|c|}{ Visual acuity } & \multicolumn{2}{|c|}{ Ophthalmoscopic features } & \multicolumn{2}{|c|}{ Fluorescein angiographic features } \\
\hline & OD & os & OD & os & OD & os \\
\hline 1 & $20 / 150$ & $20 / 20$ & $\begin{array}{l}\text { Pigment deposit, } \\
\text { temporal greying }\end{array}$ & None & Temporal leakage & Normal \\
\hline 2 & $20 / 400$ & $20 / 25$ & $\begin{array}{l}\text { Greying, atrophy, } \\
\text { cystic changes }\end{array}$ & Trace temporal greying & $\begin{array}{l}\text { Early hyperfluorescence, late } \\
\text { leakage throughout }\end{array}$ & $\begin{array}{l}\text { Subtle temporal } \\
\text { leakage }\end{array}$ \\
\hline 3 & $20 / 50$ & $20 / 25$ & $\begin{array}{l}\text { Retinal greying, right } \\
\text { angle vessels, cystic } \\
\text { changes }\end{array}$ & $\begin{array}{l}\text { Subtle pigmentary } \\
\text { stippling near fovea }\end{array}$ & Temporal leakage & Normal \\
\hline
\end{tabular}

MacTel, macular telangiectasia.

a $\sim 3.5^{\circ} \times 3.5^{\circ}$ montage centred on the foveola was generated.

Every cone photoreceptor within a $2^{\circ} \times 2^{\circ}$ area centred on the foveola was determined semiautomatically with a custom MATLAB program. ${ }^{5}$ Manual editing of cone positions was performed to correct for errors in the automated algorithm. The size of retinal features was calculated
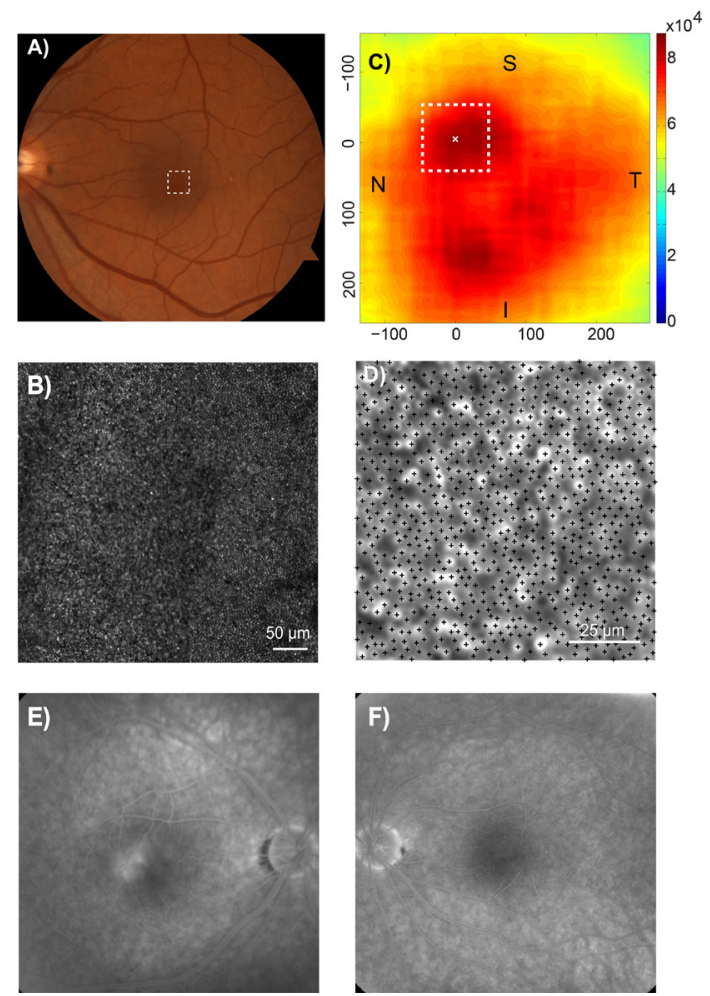

Figure 1 (A) The clinical fundus images of subject 1 in the less-affected eye. (B) Cone montage around the foveal centre (the white square in panel A). (C) Cone density map, white cross shows the peak cone density (S: superior, I: inferior, T: temporal and $\mathrm{N}$ : nasal). (D) Cone labelling, cone images correspond to the regions highlighted with a dashed box in panel C. (E) FFA image of subject 1 in the affected eye (OD) showing temporal leakage. (F) FFA image of subject 1 in the less-affected eye (OS) showing no leakage. using the axial length of each participant scaled to the Gullstrand model eye. ${ }^{6}$ The point of peak cone density was determined from the cone density map and considered the foveal centre. Using this position as a reference point, we then calculated cone density within $36 \times 36 \mu \mathrm{m}$ windows along each meridian from 0 to $2^{\circ}$ at $50 \mu \mathrm{m}$ intervals. Two-way analysis of variance (ANOVA) was used to compare the AOSLO data to the AOSLO foveal cone data of Wang $e t a l^{7}$ and the interaction between retinal eccentricities. $\mathrm{P}<0.05$ was regarded as a statistically significant difference.

\section{RESULTS}

\section{Clinical features}

Table 1 lists the clinical information for these patients.

\section{Cone density is reduced at the fovea compared with normal eyes}

The complete foveal cone mosaic was imaged in all three patients. Figure 1 shows the images from subject 1 , clinical fundus image (panel A), foveal montages (panel B), density maps (panel C) and individual cone photoreceptors within a $100 \times 100 \mu \mathrm{m}$ window centred on the point of peak density (panel D), fundus fluorescein angiography (FFA) image of the affected eye (OD, panel E) and FFA image from the less-affected eye (OS, panel F). The cone images of subject 2 and subject 3 are shown in online supplemental eFigure 1 . The peak cone density was $84.7 \times 10^{3}, 71.8 \times 10^{3}$ and $85.7 \times 10^{3}$ cones $/ \mathrm{mm}^{2}$ for participants 1,2 and 3 , respectively. For comparison to expectations in a normal population, we compared these patients to the AOSLO foveal cone density data by Wang et al. ${ }^{7}$ The average peak density from the Wang et al data is $168.047 \times 10^{3}$ cones $/ \mathrm{mm}^{2}$ (ranging from $123.611 \times 10^{3}$ to $214.895 \times 10^{3}$ ). The mean peak cone density of these three subjects with MacTel was $80.7 \times 10^{3}$ cones $/ \mathrm{mm}^{2}$, lower than the minimum peak density reported by Wang et al. Two-way ANOVA shows that cone density within $0.5^{\circ}$ in patients with MacTel is significantly lower than the normal population $(\mathrm{p}<0.05)$. 

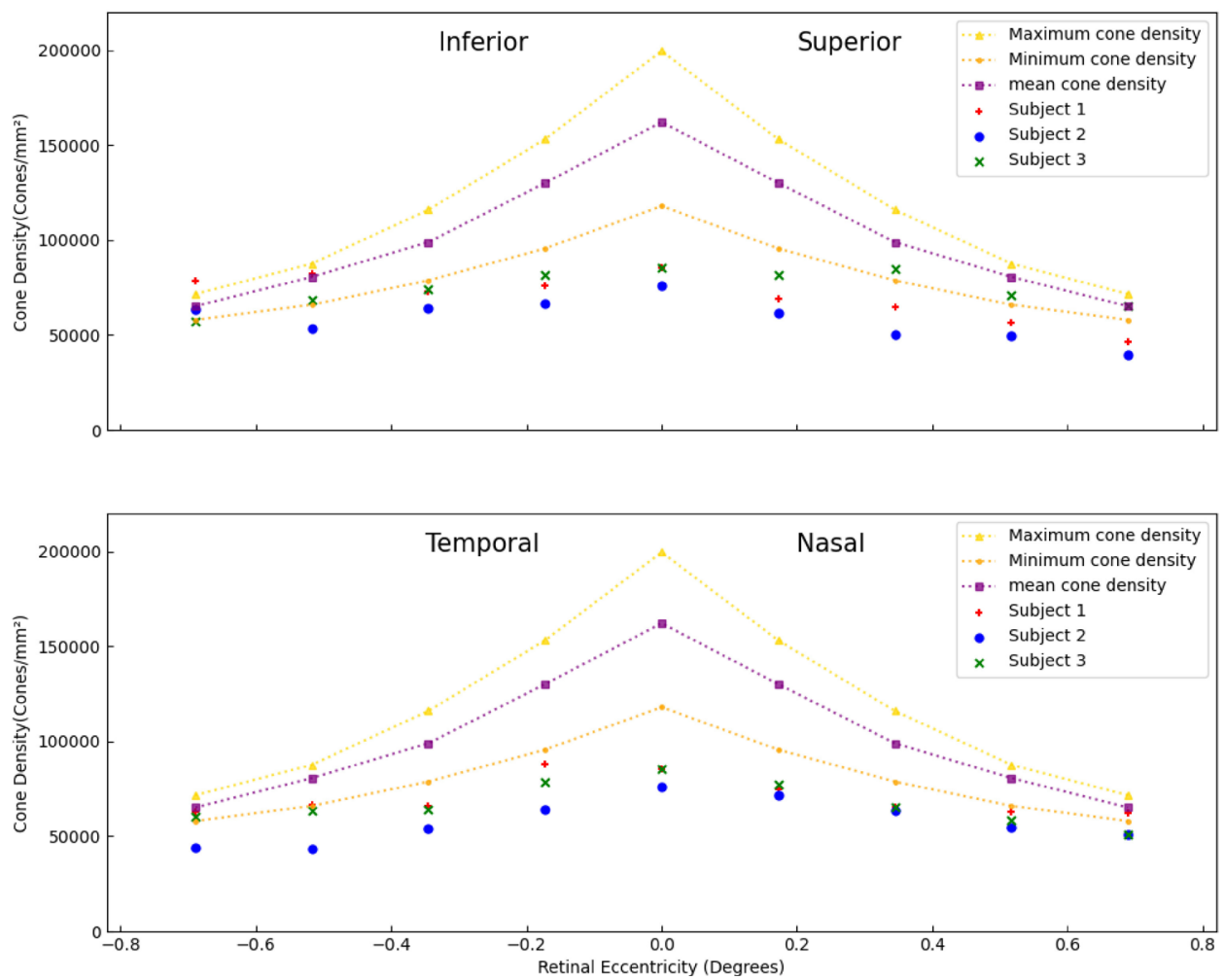

Figure 2 The measured cone packing density from the foveal centre to about $0.8^{\circ}$ at all four meridians. Curves replotted from Wang's study are depicted as dashed lines (maximum, mean and minimum cone densities).

Figure 2 shows the measured cone packing density from the foveal centre to about $0.7^{\circ}$ at all four meridians. Curves replotted from Wang et al's ${ }^{7}$ study are depicted as dashed lines (maximum, mean and minimum cone densities). Compared with the AOSLO foveal cone data from normal subjects, cone density at perifoveal area (within $0.5^{\circ}$ radius) was lower in the patients with MacTel.

\section{DISCUSSION}

Earliest microscopic change in MacTel is loss of foveal cones MacTel has traditionally been considered primarily a vascular disease affecting juxtafoveal retinal capillaries with macular oedema and exudation being the main cause for visual loss in these patients. However, Ooto et $a l^{2}$ recently reported AOSLO findings of dark regions in the extrafoveal cone mosaic and decreased cone density in those areas associated with decreased vision in a cohort of patients with type 2 MacTel. Paunescu et $a l^{8}$ and Barthelmes et $a l^{9}$ also reported optical coherence tomography (OCT) results demonstrating that the photoreceptor layer was disrupted in patients with MacTel. The patients imaged in this study were at a much earlier stage in the disease process than those reported on in these previous imaging studies with no or only subtle clinical changes in the eyes we examined. Our results suggest that at even this very early stage of MacTel, peak cone density is already lower than the minimum peak density observed for normal eyes. However, just outside the foveal centre, at $0.5^{\circ}$, these patients fall within the normal range (contrary to the report of Ooto et $a l^{2}$ ). It is also possible that with such a small number of patients, there is insufficient statistical power to detect a difference in the parafoveal retina. It should be noted that it is unclear if these patients had reduced cone density from birth or if it decreased gradually over time. Follow-up imaging needs to be performed to observe cone density change overtime both at the foveal centre and parafoveal retina to examine the rate and regional variability of progression of both photoreceptor and vascular changes.

Charbel Issa et $a l^{10}$ found decreased macular pigment (MP) in patients with MacTel. They suggested that the reduced MP may be due to either a primary loss of MP from defective trafficking or storage of MP or, a secondary loss due to pathology of the anatomical structures involved in the process of MP accumulation. ${ }^{11}$ Since MP exists in the axons of the cone photoreceptors in the central retina, ${ }^{12}$ the existence of fewer cones in the central retina provides an alternative explanation for the observed decrease in MP. A recent study ${ }^{13}$ showed Müller cell reduction in patients with MacTel type 2. Müller cells play an important role in photoreceptor development and survival. ${ }^{14}$ It has been reported that a targeted disruption of Müller cell metabolism adversely affected the assembly of the photoreceptor outer segment membrane and photoreceptor dysmorphogenesis can result from the compromise of Müller cells. ${ }^{15}$ Because of poor preservation of photoreceptors in all the samples, they could not determine if there was 
a reduction of cone numbers in the MacTel fovea. It is possible that the reduced cone photoreceptor density we observed in patients with MacTel is related to a depletion or dysfunction of Müller cells.

High-resolution imaging studies provide unprecedented microscopic disease characterisation in the living eyes of patients that may be very valuable for better understanding rare diseases such as MacTel. The reduced foveal cone density in the clinically lessaffected eyes in patients with asymmetric MacTel that we observe here suggests that future studies with highresolution imaging capabilities should not only focus on the vasculature, but also on the photoreceptors in the fovea. It is possible that foveal cone photoreceptor loss may precede the classic obvious vascular changes observed at later stages in MacTel, or the foveal cone loss may happen concurrently with the vascular changes.

Acknowledgements The authors wish to thank Mina M Chung, who passed away during the drafting of this manuscript, for her essential contributions to this work. Dr Chung was a talented and compassionate surgeon, a thoughtful clinicianscientist and a wonderful mentor and friend.

Contributors All authors planned the study. HS collected and analysed the data and submitted the study. All authors wrote the discussion.

Funding This work was supported by the National Eye Institute (EY021786, EY021669, EY001319, EY014375 and EY004367), Research to Prevent Blindness, Fight for Sight(ER), Lowy Medical Foundation, Capital's Fund for Health Improvement and Research (2018-2z-1082)

Competing interests None declared.

Patient consent for publication Not required.

Provenance and peer review Not commissioned; externally peer reviewed.

Data availability statement Data are available upon request.

Supplemental material This content has been supplied by the author(s). It has not been vetted by BMJ Publishing Group Limited (BMJ) and may not have been peer-reviewed. Any opinions or recommendations discussed are solely those of the author(s) and are not endorsed by BMJ. BMJ disclaims all liability and responsibility arising from any reliance placed on the content. Where the content includes any translated material, BMJ does not warrant the accuracy and reliability of the translations (including but not limited to local regulations, clinical guidelines, terminology, drug names and drug dosages), and is not responsible for any error and/or omissions arising from translation and adaptation or otherwise.

Open access This is an open access article distributed in accordance with the Creative Commons Attribution Non Commercial (CC BY-NC 4.0) license, which permits others to distribute, remix, adapt, build upon this work non-commercially, and license their derivative works on different terms, provided the original work is properly cited, appropriate credit is given, any changes made indicated, and the use is non-commercial. See: http://creativecommons.org/licenses/by-nc/4.0/.

ORCID iD

Hongxin Song http://orcid.org/0000-0002-3653-6654

\section{REFERENCES}

1 Charbel Issa P, Helb H-M, Rohrschneider K, et al. Microperimetric assessment of patients with type 2 idiopathic macular telangiectasia Invest Ophthalmol Vis Sci 2007:48:3788-95.

2 Ooto S, Hangai M, Takayama K, et al. High-Resolution photoreceptor imaging in idiopathic macular telangiectasia type 2 using adaptive optics scanning laser ophthalmoscopy. Invest Ophthalmol Vis Sci 2011;52:5541-50.

3 Jacob J, Krivosic V, Paques M, et al. Cone density loss on adaptive optics in early macular telangiectasia type 2. Retina 2016;36:545-51.

4 Song $\mathrm{H}$, Rossi EA, Latchney $\mathrm{L}$, et al. Cone and rod loss in Stargardt disease revealed by adaptive optics scanning light ophthalmoscopy. JAMA Ophthalmol 2015;133:1198.

5 Song $\mathrm{H}$, Chui TYP, Zhong Z, et al. Variation of cone photoreceptor packing density with retinal eccentricity and age. Invest Ophthalmol Vis Sci 2011;52:7376-84.

6 Almeida MSde, Carvalho LA. Different schematic eyes and their accuracy to the in vivo eye: a quantitative comparison study. Brazilian Journal of Physics 2007;37:378-87.

7 Wang Y, Bensaid N, Tiruveedhula P, et al. Human foveal cone photoreceptor topography and its dependence on eye length. Elife 2019;8. doi:10.7554/eLife.47148. [Epub ahead of print: $26 \mathrm{Jul} 2019$ ].

8 Paunescu LA, Ko TH, Duker JS, et al. Idiopathic juxtafoveal retinal telangiectasis: new findings by ultrahigh-resolution optical coherence tomography. Ophthalmology 2006;113:48-57.

9 Barthelmes D, Gillies MC, Sutter FKP. Quantitative OCT analysis of idiopathic perifoveal telangiectasia. Invest Ophthalmol Vis Sci 2008:49:2156-62.

10 Charbel Issa P, van der Veen RLP, Stijfs A, et al. Quantification of reduced macular pigment optical density in the central retina in macular telangiectasia type 2. Exp Eye Res 2009;89:25-31.

11 Helb H-M, Charbel Issa P, VAN DER Veen RLP, et al. Abnormal macular pigment distribution in type 2 idiopathic macular telangiectasia. Retina 2008;28:808-16.

12 Snodderly DM, Auran JD, Delori FC. The macular pigment. II. spatial distribution in primate retinas. Invest Ophthalmol Vis Sci 1984;25:674-85

13 Powner MB, Gillies MC, Tretiach M, et al. Perifoveal Müller cell depletion in a case of macular telangiectasia type 2. Ophthalmology 2010;117:2407-16.

14 Reichenbach A, Stolzenburg JU, Eberhardt W, et al. glial) cells do for their neuronal 'small siblings'? Journal of Chemical Neuroanatomy 1993;6:201-13.

15 Jablonski MM, lannaccone A. Targeted disruption of Müller cell metabolism induces photoreceptor dysmorphogenesis. Glia 2000;32:192-204. 